This is the peer reviewed version of the following article: [Fernández, S. et al. Land Degradation \& Developmen, 27(5), p. 1479-1488 (2016)], which has been published in final form at [http://dx.doi.org/10.1002/ldr.2452]. This article may be used for non-commercial purposes in accordance with Wiley Terms and Conditions for Self-Archiving. 


\section{SPATIAL MODELLING OF ORGANIC CARBON IN BURNED MOUNTAIN SOILS USING HYPERSPECTRAL IMAGES, FIELD DATASETS, AND NIR SPECTROSCOPY (CANTABRIAN RANGE; NW SPAIN)}

Susana Fernández ${ }^{1,2^{*}}$, Juanjo Peón ${ }^{2,3}$, Carmen Recondo ${ }^{2,3}$, Javier F. Calleja ${ }^{4}$, César Guerrero $^{5}$

${ }^{1}$ Department of Geology, University of Oviedo, C/ Jesús Arias de Velasco s/n, 33005 Oviedo, Asturias, Spain

${ }^{2}$ Institute of Natural Resources and Spatial Planning (INDUROT), University of Oviedo, C/ Gonzalo Gutiérrez Quirós s/n, 33600 Mieres, Asturias, Spain

${ }^{3}$ Area of Cartographic, Geodesic and Photogrammetric Engineering, Department of Mining Exploitation and Prospecting, University of Oviedo, C/ Gonzalo Gutiérrez Quirós s/n, 33600 Mieres, Asturias, Spain

${ }^{4}$ Department of Physics, Polytechnic School of Mieres, University of Oviedo, C/ Gonzalo Gutiérrez Quirós s/n, 33600 Mieres, Asturias, Spain

${ }^{5}$ Departament of Agrochemistry and Environment, University Miguel Hernández, Avda. Universidad s/n, 03202 Elche, Alicante, Spain

Corresponding author:

Susana Fernández. Department of Geology, University of Oviedo, C/ Jesús Arias de Velasco s/n, 33005 Oviedo, Asturias, Spain. Tel: +34 985103180. Fax: +34 985458110 E-mail: fernandezmsusana@uniovi.es 


\begin{abstract}
Soil organic matter is seriously affected by fires and suffers changes in stock, composition, and distribution. In the North-West side of the Cantabrian Range (northern Spain) fires are very common. In order to develop a cartographic technique to map areas with high carbon stocks caused by fire, we test a technique based on calibrated VIS-NIR soil organic carbon models and hyperspectral images. Total (TOC) and oxidizable carbon (OC) were measured in 89 soil samples. The samples were scanned with VIS-NIR spectrometer $(400-2500 \mathrm{~nm})$ and the spectra were resampled to the hyperspectral image channels. Spectroscopic models for TOC and OC were fitted $\left(\mathrm{R}^{2}>\right.$ 0.81) using partial least squares regression (PLSR). The predictions were regionalized to the hyperspectral image and the results validated with a new soil population consisting of twelve Valeri plots collected in burned slopes of the study area under heather vegetation. In soil samples, TOC and OC values are highly correlated $(R=0.92)$ and the coefficients of the PLSR models have a similar pattern, which suggests similar organic components. Nevertheless, there are significant differences in the values of the regression coefficients, much higher in the TOC model except at 560 and $2054 \mathrm{~nm}$ that might be interpreted as labile carbon components, and at $1590 \mathrm{~nm}$. At this wavelength the coefficient of TOC is positive and OC is negative, and it could be interpreted as hydrocarbons components present in the TOC model.
\end{abstract}

Keywords: Total Organic Carbon, Oxidizable Organic Carbon, Soil Organic Carbon Mapping, VIS-NIR Spectroscopy, Hyperspectral Remote Sensing 


\section{INTRODUCTION}

Soil organic carbon (SOC) is an essential component of organic matter (SOM) that plays a key role in soil chemical and physical properties, affecting bulk density, nutrient availability, structural stability, hydraulic conductivity, and soil biodiversity. SOC is the largest terrestrial carbon pool with an estimated content of $1600 \mathrm{Pg}$ for the first meter of soil depth (Novara et al., 2011). Soil organic carbon pools are essential to climate control through the regulation of $\mathrm{C}$ and $\mathrm{N}$ fluxes and support primary production of the ecosystems (Brevik et al., 2015). In an undisturbed ecosystem such as natural forest, soil carbon is stable over time (steady-state) and soil carbon mineralization is balanced by organic matter production (Novara et al., 2011), and most of the carbon is stored as partially decomposed organic matter (Schulze et al., 2000). The remaining nonmineralized carbon undergoes slow oxidation processes and is stabilized as humic substances. Changes suffered by organic matter are the result of microbial activity (Guénon et al., 2013; Wang et al., 2015), but also can be originated by abiotic transformations induced by external factors, among which fire is a major one (Hatcher $\&$ Spiker, 1988). Some authors have reported an increase of the SOM content in areas affected by fire (Czimczik \& Masiello, 2007; Fernández-Menéndez et al., 2011; Johnson \& Curtis, 2001; Knicker, 2007; Santín et al., 2015; Santin et al., 2008). It is widely accepted that fire causes alterations in physical, chemical and biological soil properties (Mataix-Solera \& Guerrero, 2007; Neary et al., 1999; Úbeda \& Outeiro, 2009). In soil organic matter fires lead not only to the formation of new thermallycondensed products, but also to the transformation of labile compounds into recalcitrant organic forms (Gonzalez-Perez et al., 2004), all of them contributing to long-term C and N sequestration in soils (Kuhlbusch \& Crutzen, 1995; Schmidt \& Noack, 2000). In this way, Hajdas et al. (2007) found biochar from Pinus sp. in the B-C soil horizons boundary of an Australian soil dated 11.180 75 and 11.270-10.980 BP. Therefore, burned soils could represent a carbon sink of great importance and with potential impact on the global carbon cycle (Kuhlbusch, 1998).

Annually $0.6 \mathrm{M}$ ha of forest ecosystems are affected by fires in Europe (FAO, 2001). In the western part of the Cantabrian Mountain Range, northern Spain, the use of fire for millennia has modified the vegetation cover (Díaz González \& Fernández Prieto, 1994) and promoted intense soil transformations. Former research in the area concluded that fires influence the rates of SOC sequestration, carbon stocks of $32 \mathrm{Mg} / \mathrm{ha}$ and $90 \mathrm{Mg} / \mathrm{ha}$ were measured in unburned and burned soils, respectively (FernándezMenéndez et al., 2011).

Fires alter SOC (Czimczik \& Masiello, 2007; Gonzalez-Perez et al., 2004; Knicker, 2007; Santin et al., 2008) but the resulting SOM quantity and distribution in the landscape depend not only on losses by combustion and inputs of charred materials (Knicker et al., 2005) but also on post-fire erosion and sedimentation processes and landscape redistribution (Rumpel et al., 2006). In these processes the presence of ash layer plays an important role because it provides substantial SOM protection after fire episode. In this way, Cerdà \& Doerr (2008) obtained that a $34 \mathrm{~mm}$ ash cover alone can reduce surface runoff from small plots by more than one, and sediment yield by more than two orders magnitude for a 1-hour, $55 \mathrm{~mm} \mathrm{~h}^{-1}$ rainstorm. Nevertheless in steep slopes the ash spatial variability increased with time as a result of water erosion (Pereira et al., 2013). Knowledge of soil carbon distribution in landscape using conventional analytical methodologies is further complicated by its high spatial variability (Ellert et 
al., 2001). Development of methods for soil carbon analysis that address and minimize the uncertainties associated with conventional methodologies are important for improving estimates of terrestrial carbon inventories and fluxes (Burres et al., 2001). In this way, remote sensing offers the possibility of spatial and temporal estimates of land cover and land management which impact soil carbon dynamics (Gehl \& Rice, 2007). Nevertheless, research reporting the direct quantification of SOC or SOM content in the upper layer of soils using remote sensing has been limited to agricultural or bare soil areas (Ben-Dor et al., 2002; Gomez et al., 2012; Patzold et al., 2008; Selige et al., 2006; Uno et al., 2005). Relationships between visible reflectance, soil colour and organic carbon are the most common direct way to predict the organic carbon content in soils using satellite images from optic sensors (Chen et al., 2000; Steinhardt \& Franzmeier, 1979). But when soils are partially covered by vegetation, as it is the case of burned slopes covered by heather, the spectral signature in each pixel of image corresponds to mixed signal from soil and vegetation.

We understand that separating the vegetation and soil contributions to the signal detected by the sensor is a key question for building valid soil carbon models using satellite imagery with optical sensors. However, in optical images, a complete removal of the vegetation signal is not possible. Nevertheless, the use of soil lab optical spectra $(400-2500 \mathrm{~nm})$ together with hyperspectral images can help to minimize the vegetation signal. This is possible because, unlike multispectral imagery, hyperspectral remote sensing provides a quasi-continuous spectrum for each pixel, which enables the spectral identification of minerals, rocks, or soils with similar laboratory reflectance spectral properties at the remote sensing scale (Chabrillat et al., 2002).

On one hand, reflectance spectroscopy laboratory analysis provides a rapid and non-destructive method for soil carbon measurement based on diffusely reflected radiation of an illuminated soil sample (Gehl \& Rice, 2007; Guénon et al., 2013). Diffuse reflectance spectroscopy in the visible and near infrared region (VIS-NIR, 400$2500 \mathrm{~nm}$ ) has been widely applied to quantify soil carbon successfully, often with reported $\mathrm{R}^{2}$ values greater than 0.80 (Ben-Dor \& Banin, 1995; Chang \& Laird, 2002; Chang et al., 2001; Janik et al., 1998; McCarty et al., 2002; Morra et al., 1991). Calibration methods are used to relate lab-spectra to soil analyses, including multiple linear regression (MLR), principal component regression (PCR), and partial least squares regression (PLSR) (Viscarra Rossel \& Behrens, 2010; Viscarra Rossel et al., 2006). Of special interest are recent works in which SOM was partitioned into fractions with different time of residence in soils. In this way, Vasques et al. (2009) obtained labile and recalcitrant soil organic carbon forms and used PLSR techniques to construct accurate models to predict these fractions. On the other hand, the application of satellite hyperspectral imagery to measure soil properties has rarely been reported (Croft et al., 2012; Gomez et al., 2008; Lu et al., 2013), and only data from the Hyperion sensor (400-2500 nm) on board the Earth Observing-1 (EO-1) satellite have been used. Several studies used data from airborne hyperspectral sensor HyMap (400-2500 nm) to generate PLSR models for SOC: Hbirkou et al. (2012), Patzold et al. (2008), and Selige et al. (2006) in agricultural fields in Germany ( $\mathrm{R}^{2}$ of $0.83,0.74$, and 0.90 respectively). Data from the airborne sensor AHS (430-2540 nm) were also used to calibrate SOC models (Stevens et al., 2010; Stevens et al., 2008). These models had limited predictive ability, but the results showed the potential of imaging spectroscopy as an alternative to conventional analytical techniques. A review of several studies dealing with the 
estimation of SOC from airborne and space-borne sensors and with challenges in achieving accurate predictions is given by Croft et al. (2012).

The objectives of this research were: i) test the use of hyperspectral images and VIS-NIR lab-spectra of soils to map oxidizable and total organic carbon in hard to reach areas partially covered by vegetation and affected by fires, and ii) by comparing OC and TOC PLSR models approaching the molecular composition of both soil organic matter components in terms of residence times.

\section{MATERIALS AND METHODS}

\section{Location and geological setting}

The study area is located in the Cantabrian Mountains (NW of Spain), in the western part of the mountain range which runs parallel to the northern coast of Spain (Figure 1). The climate is oceanic, with mean annual rainfall of $1500 \mathrm{~mm}$, and moderate temperatures, with mean annual values ranging between 6.5 and $10.7^{\circ} \mathrm{C}$. The orography corresponds to low-middle mountain areas, with altitudes between 200 and $1200 \mathrm{~m}$ and average slopes between $10^{\circ}$ and $30^{\circ}$. In this part of the Cantabrian Range an area of approximately $60 \mathrm{~km}^{2}$ running SE-NW (Figure 1) was selected to conduct a flight campaign to obtain hyperspectral images. The geological and geomorphological characteristics of this area, together with the large history of forest fires, make it highly suitable for this study. The bedrock is mainly formed by sandstone, quartzite, and slates, giving rise to a high degree of lithological homogeneity. A large part of this substratum is covered by a coarse regolith exhibiting a grain-supported fabric with continuous soil cover. The soils developed over these bedrocks are Histosols and Regosols (WRB, 2014) with poorly evolved profile, sandy and stony, as well as very rich in organic matter (Fernandez et al., 2005) (Figure 2).

\section{Forest fires and soils}

Historically, livestock farming has given rise to the repeated burning of extensive areas, which has caused severe degradation of soil and natural vegetation. At present, the majority of the slopes are deforested, alternating gorse-briar scrubland with stony areas where the soil has completely disappeared. The dominant vegetation is oceanic heaths formations (Erica australis subsp. aragonensis (Willk.) Cout. and Calluna vulgaris (L) Hull), a result of the degradation suffered by the natural vegetation caused by forest fires (Díaz González \& Fernández Prieto, 1994). As for the natural forest formations, at present, these have been reduced to different types of oak groves (Quercus petraea subsp. Petraea (Matt.) Liebl., Quercus robur L., and Quercus pyrenaica Willd.) (Figure 2).

During the first half of the 20th century forest fires occurred with extreme frequency in the north of the Iberian Peninsula, and in recent years fires are still very frequent in the area. Recent studies of the area and neighbouring locations show alterations of properties of the burnt soils, like significant loss in clay contents and textural and structural degradation which affect the hydrologic behaviour of burned soils, increased infiltration rates $(0.0107$ to $0.1070 \mathrm{~cm} / \mathrm{s}$, Fernandez et al., 2005), and enhanced soil erosion, with average values of soil losses, measured with ${ }^{137} \mathrm{Cs}$ on burned slopes around $6.5 \mathrm{t} \mathrm{ha}^{-1}$ year $^{-1}$ (Duarte et al., 2008). Fires also affected soil organic matter. Santin et al. (2008) measured TOC concentration in the surface layer (0-5 cm depth) ranging from $390.2 \mathrm{mg} \mathrm{g}^{-1}$ for soil in the burned slopes covered by heaths to $157.1 \mathrm{mg}$ 
$\mathrm{g}^{-1}$ for soil in the non-burned forest. In the subsurface layer $(5-10 \mathrm{~cm}$ depth), TOC accumulation is significantly lower, with values ranging from $289.5 \mathrm{mg} \mathrm{g}^{-1}$ for soil in the burned slopes to $70.7 \mathrm{mg} \mathrm{g}^{-1}$ in non-burned soils.

\section{Field soil sampling}

Soil sampling was carried out in the summer of 2013. Two types of samples were collected and its geographical position was recorded by a Global Positioning System (GPS) device. 89 surface soil samples from the upper $5 \mathrm{~cm}$ were collected randomly from three areas located in the south, north, and in the middle of the study area trying to cut the spatial gradient associated to the abundance of heaths, which are clearly higher in the north of the study area (Figure 2). All the samples were taken in the heathery slopes because this vegetation cover comes from the fire management of the territory (Díaz González \& Fernández Prieto, 1994). In addition, for validation and in order to ameliorate the image pixel size effect, 12 Valeri plots (Rossello \& Baret, 2007) with $15 \times 15$ meters were used to estimate the full spectral variability on soils. Twelve samples were collected by mixing 5 samples gathered at the corners and the centre of each plot.

\section{Soil carbon analysis}

The soil samples were dried at $70^{\circ} \mathrm{C}$, sieved at $2 \mathrm{~mm}$, homogenized and divided into two parts: the first for chemical analysis and the second for spectral analysis in the laboratory. The total $\mathrm{C}$ (TOC) concentrations were determined, in duplicate, by means of dry combustion at $950^{\circ} \mathrm{C}$ (Elemental Vario EL CN-Analyzer). Oxidizable Carbon (OC) was analysed with dichromate oxidation method (Walkley \& Black, 1934).

\section{Laboratory spectroscopy}

The diffuse reflectance spectra of the sieved soil samples were obtained using the VIS-NIR spectrometer LabSpec ${ }^{\circledR} 2600$ (Analytical Spectral Devices Inc., USA). Samples were scanned using a Hi-Brite Contact Probe with built-in light source and a spot size of $10 \mathrm{~mm}$. A Spectralon ${ }^{\circledR}$ panel was used as white reference. Ten measurements per sample were collected and then averaged in order to obtain a representative spectrum of each soil sample.

\section{Imaging spectroscopy}

A flight campaign was conducted over the study area by the National Institute for Aerospace Technology (INTA). Airborne hyperspectral data were collected at 11:05 UTC on $10^{\text {th }}$ October 2011 at an altitude of $2987 \mathrm{~m}$ above the sea level ( $9800 \mathrm{ft}$ ), using the AHS sensor. This sensor has 80 channels: 63 in the reflective part of the spectrum (visible and near infrared, VIS-NIR), 7 in the $3177-5251 \mathrm{~nm}$ region (mid infrared, MIR) and 10 in the 8310-12952 nm range (thermal infrared, TIR). Reflective channels were the only ones used in this study: 20 channels between 443 and $1001 \mathrm{~nm}$ with Full Width at Half Maximum (FWHM) ranging from 27 to $29 \mathrm{~nm}, 1$ channel centred at $1590 \mathrm{~nm}$ with FWHM of $85 \mathrm{~nm}$, and 42 between 1924 and $2553 \mathrm{~nm}$ with FWHM of $14-18 \mathrm{~nm}$. It is worth mentioning that in remote sensing the 1300-2500 nm region is usually referred as short wave infrared (SWIR), while in spectroscopy it is considered as NIR. This last notation was used in this article. At sensor radiance data were corrected by INTA using Atmospheric \& Topographic Correction (ATCOR-4) to 
obtain Hemispherical Directional Reflectance Factor (HDRF). Then data were georeferenced to the coordinate system Universal Transverse Mercator (UTM), datum World Geodetic System 1984 (WGS-84), zone 30 north; with a spatial resolution of $5 \mathrm{~m}$. Channels of the 1924-2553 nm region that were affected by noise, those with Signal-to-Noise Ratio (SNR) lower than 10, were removed, 24 in total. One channel of the VIS-NIR region was also removed due to an incorrect atmospheric correction. A total of 38 reflective channels were considered for further analysis.

\section{Spectra preprocessing and modelling of soil properties}

Lab-spectra of the 89 soil samples were shortened from $350-2500 \mathrm{~nm}$ to $400-2450 \mathrm{~nm}$ in order to remove noise at the beginning and end of each spectrum. Then they were spectrally resampled to match the response of the AHS sensor. After the resampling process, the 2051 channels of the lab-spectra were resampled to 38 new channels with the spectral resolution of the AHS sensor. Several preprocessing techniques were tested in the spectra before modelling and the best ones were identified by maximizing the ratio of performance to deviation (RPD). Reflectance spectra were converted to $\log (1 /$ reflectance $)$, since the prediction ability of the models improved with this transformation.

The technique used for modelling TOC and OC was the PLSR method (Wold et al., 2001), a common multivariate statistical technique used in chemometrics, as well as in the quantitative spectral analysis of soils. It allows to construct predictive models when there are many predictor variables that are highly collinear. By fitting a PLSR model, one hopes to find a few PLSR factors that explain most of the variation in both predictors and responses (Haaland \& Thomas, 1988; Viscarra Rossel et al., 2006). Two types of PLSR models were calibrated for each soil property using VIS-NIR data, one with the lab-spectra between $400-2450 \mathrm{~nm}$ (2051 channels) and another with the resampled spectra to the AHS sensor (38 channels) (Figure 3). The number of factors to include in each model was selected by leave-one-out cross-validation. The optimal number of factors was chosen by minimizing the Akaike Information Criterion (AIC), in order to avoid under- and over-fitting (Akaike, 1969). The lower the AIC is, the better the model is. The regression coefficients of the PLSR models (b) were plotted to identify the most important spectral regions for the prediction of each soil property.

In order to obtain spatially continuous maps of both soil properties, the PLSR models calibrated with the lab-spectra resampled to the AHS were applied pixel by pixel to the AHS image, after the geometric and atmospheric correction. Digital maps of both soil properties were obtained with a spatial resolution of $5 \mathrm{~m}$ (Figure 3).

\section{Validation and scaling methods}

The quality of the PLSR models was evaluated by means of several parameters obtained in the leave-one-out cross-validation: the coefficient of determination $\left(\mathrm{R}^{2} \mathrm{cv}\right)$, the root mean square error $\left(\mathrm{RMSE}_{\mathrm{cv}}\right)$, and the ratio of performance to deviation (RPD). RPD is the ratio of the standard deviation of the reference data to the RMSE of cross-validation. Chang et al. (2001) defined three categories of models based on the value of RPD: models in category I (RPD>2) are considered to accurately predict the soil property, models in category II ( $2>$ RPD $>1.4)$ belong to an intermediate class and have a limited predictive power, and models in category III (RPD $<1.4)$ have no prediction ability.

On the other hand, the predictive power of the TOC and CO maps was evaluated using the independent validation dataset consisting of 12 Valeri plots. A mean filter 
with kernel size $3 \times 3$ was applied to the maps of soil properties in order to obtain a representative value of the $15 \times 15 \mathrm{~m}$ Valeri plot, and then compared to the values of reference. The parameters used to evaluate the difference between the reference and the predicted values by the maps were the $\mathrm{R}^{2}$, residual standard error (RSE), root mean square error of prediction (RMSEP), and Bias for the mean of the residuals. The results of the validation were satisfactory in terms of $\mathrm{R}^{2}$ and RSE, but not in terms of RMSEP and Bias. The overestimation of each map was corrected by means of a linear fit, adjusted using the estimated and reference values of two randomly chosen plots. Finally, the remaining 10 plots were used for an independent validation of the scaled maps.

\section{RESULTS AND DISCUSSION}

\section{Soil samples descriptive analysis}

The results of the chemical analysis obtained in the lab for the 89 soil samples (individual samples) and for the 12 Valeri plots are summarized in Table I. A strong positive correlation was observed between both soil properties, TOC and OC, with a Pearson correlation coefficient (R) of 0.92 in the individual soil samples and 0.97 in the plot samples. The range of both TOC and OC are high but in accordance with the results obtained by Fernandez et al. (2005) and Santin et al. (2008) in the same area. The maximum values of $63.2 \%$ (TOC) or $37.9 \%$ (OC) could have a geomorphological origin related to the accumulation of extensive mantles of organic soil in remaining paleo surfaces, located mainly in the north of the study area. On the other hand, the lowest values of TOC and OC ( $4.3 \%$ and $2.7 \%$, respectively) are related to the erosive degradation suffered by burned slopes in which the soil parent material corresponds mainly to coarse regolithic with grain-supported fabric. Frequent fires in these slopes caused very intense soil degradation and as a result these soils have extremely thin organic horizons (Duarte et al., 2008; Fernandez et al., 2005).

\section{PLSR models of soil organic carbon}

Several preprocessing techniques were tested in the spectra before the PLSR modelling. The best preprocessing for both soil properties was the transformation from reflectance (R) to $\log (1 / \mathrm{R})$, and was applied to all the spectra. These results are in accordance with Vasques et al. (2009) and Viscarra Rossel et al. (2006), who also obtained the best models for TOC prediction using this transformation. PLSR settings and model performance statistics are summarized in Table II, and the PLSR regression coefficients obtained using the resampled spectra are plotted in Figure 4. Accurate PLSR models were obtained for both soil properties and spectral resolution (entire lab-spectra or lab-spectra resampled to AHS), with $\mathrm{R}^{2}$ cv values between 0.78 and 0.89 , and RPD ranging from 2.13 to 2.97. According to the model classification based on RPD by Chang et al. (2001), models provide accurate predictions. The best predictions were obtained for OC, with RMSE $\mathrm{cv}$ of 3.5\% and an RPD of $~ 3$; and slightly worse for TOC, with $\mathrm{RMSE}_{\mathrm{cv}}$ of $\sim 6.5 \%$ and an RPD of $\sim 2.2$. The prediction ability of the models was similar to that obtained in other works in which soil organic carbon was also modelled using lab-spectra and PLSR: Chang \& Laird (2002) $\left(\mathrm{R}^{2}=0.89\right)$, Martin et al. (2002) $\left(\mathrm{R}^{2}=0.75, \mathrm{RPD}=1.97\right)$, and McCarty et al. $(2002)\left(\mathrm{R}^{2}=0.82\right)$.

Despite the high contrast in the number of channels of both spectral resolutions in Table II, no significant differences were observed between models using the entire 
lab-spectra (2051 channels) or the lab-spectra resampled to the AHS sensor (38 channels). Slightly better results were even obtained using the resampled spectra. These results show the high potential of hyperspectral remote sensing for organic carbon mapping, and are in accordance with the results obtained by Gomez et al. (2008), who found that the spectral resolution did not significantly change the accuracy of the PLSR models when the lab-spectra were resampled to the hyperspectral sensor Hyperion, regardless of the organic carbon ranges and the number of samples. Lu et al. (2013) evaluated the performance of PLSR models for SOC prediction and other soil properties using three spectral settings: lab, Hyperion image, and lab resampled to Hyperion. Their model for SOC based on resampled spectra was slightly less accurate than that based on the entire lab-spectra, but still provided a moderately satisfactory result $\left(\mathrm{R}^{2}=0.74, \mathrm{RPD}\right.$ $=1.98)$.

In general, between 1000 and $2500 \mathrm{~nm}$ there are several absorption peaks in both models corresponding to overtones and combinations of fundamental vibrations of $\mathrm{C}-\mathrm{O}$, $\mathrm{O}-\mathrm{H}, \mathrm{C}=\mathrm{O}, \mathrm{C}-\mathrm{H}$, and $\mathrm{N}-\mathrm{H}$ bonds that are present in organic compounds such as proteins, starch, cellulose, humic acids, and lignin (Ben-Dor et al., 1997; Huang et al., 2008). These absorptions are however difficult to attribute to a single component since they are greatly overlapping in the VIS-NIR. The coefficients of the PLSR models obtained with the resampled spectra are plotted in Figure 4 as a function of wavelength, and in Table III the positive PLSR values and the corresponding wavelengths are given. In general, peaks in TOC model are higher than in OC model probably as a consequence of a greater amount of organic components in TOC model. This can be related to the chemical extraction methods (oxidization and dry combustion) more effective in TOC extraction (Tessier et al., 1979). Nevertheless, at $560 \mathrm{~nm}$ and $2054 \mathrm{~nm}$ there are absorption peaks that show higher value in OC than in TOC model. These peaks correspond to the most labile carbon fractions in Vasques et al. (2009) interpretation and to extractive lignine and carbohydrates in Huang et al. (2008) interpretation. These results seem to highlight the more labile nature of the OC model components. The rest of coefficients are higher in TOC than in OC model showing a greater amount of stable soil carbon components. A negative regression coefficient was obtained at $1590 \mathrm{~nm}$ in the OC model. This wavelength is significant in this work because it corresponds to a wideband $(85 \mathrm{~nm})$ bringing together the NIR bands information and moreover it was the only NIR band in the range between 1000 and $2000 \mathrm{~nm}$ that has been used in the models. The rest of the bands in this interval of the hyperspectral image had to be removed due to noise problems. According to the literature, this band could be associated with crystalline cellulose and lignine (Huang et al., 2008; Viscarra Rossel, $2007)$ and also could be related to hydrocarbons components $(\sim 1647, \sim 1712 \mathrm{~nm})$ present only in TOC model and associated to fire organic carbon transformations (Okparanma \& Mouazen, 2013) but it is not easy to interpret in our results. At 2181, 2196, 2212, and $2227 \mathrm{~nm}$ in both models there is an intense negative peak (Figure 4) which could be related to biochar components or intensely mineralized organic components (Bellon-Maurel \& McBratney, 2011; Vasques et al., 2009).

\section{Maps of soil organic carbon}

PLSR models for TOC and OC were applied to the AHS image in order to obtain maps of both properties in the upper $5 \mathrm{~cm}$ of soils. The independent validation dataset consisting of 12 Valeri plots was used to evaluate the accuracy of these maps. The best results of the analysis between the reference and the predicted values were obtained for 
OC, with $\mathrm{R}^{2}$ of 0.74 and RSE of $4.5 \%$; and slightly worse for TOC, with $\mathrm{R}^{2}$ of 0.74 and RSE of $6.0 \%$. However, the analysis of the RMSEP and Bias showed that maps tend to strongly overestimate both soil properties, with RMSEP values higher than $40 \%$ and Bias of about $-40 \%$, probably due to the signal from the vegetation in the spectra from the image, not considered in lab calibrations based on soil spectra. Maps of soil properties were scaled using a linear fit based on data from two plots, and the performance of the maps was evaluated again using the remaining 10 plots (Table IV). The scatter plot of observed against estimated soil properties after the scaling is shown in Figure 5. As expected, very similar $\mathrm{R}^{2}$ and RSE values were obtained after the scaling, and a significant improvement was observed in the RMSEP and Bias. The validation of the scaled maps was satisfactory for both soil properties, TOC $\left(R^{2}=0.73\right.$, RMSEP $=7.8 \%)$ and OC $\left(\mathrm{R}^{2}=0.72\right.$, RMSEP $\left.=5.1 \%\right)$, with an accuracy only slightly lower than that obtained in the lab (see Table II). For illustration purposes, the spatial distribution of the predicted TOC and OC content in a slope located in the south of the study area is shown in Figure 6. Maps in Figure 6 were smoothed using a mean filter of kernel size $3 \times 3$ in order to improve the outcomes, and to clearly show the variation in the soil properties within the slope.

Several studies used data from the AHS sensor to obtain spatially continuous maps of soil organic carbon, but all of them in bare soils. Model for SOC prediction in agricultural fields by Stevens et al. (2008) only explained $52.7 \%$ of the SOC variation, whereas Stevens et al. (2010) obtained better results in croplands $\left(\mathrm{R}^{2}=0.75\right)$, but still with limited accuracy (RMSEP of $\sim 3 \mathrm{~g} \mathrm{C} \mathrm{kg}^{-1}$ ). Data from the airborne sensor HyMap were also used for SOC prediction in agricultural fields and slightly better results were obtained: Hbirkou et al. $(2012)\left(\mathrm{R}^{2}=0.83\right)$, Patzold et al. $(2008)\left(\mathrm{R}^{2}=0.74\right)$, and Selige et al. (2006) $\left(\mathrm{R}^{2}=0.90\right)$. All these works, and also the one presented here, are limited to the upper layer of soils $(0-5 \mathrm{~cm})$, since all of them are based on remotely sensed data collected in the optical region of the spectrum $(400-2500 \mathrm{~nm})$, which capacity to penetrate in soil is very limited and restricted to the surface layer. In this work, topsoil organic carbon was modelled in a complex domain far from the bare soil ideal conditions, since soils were partially covered by vegetation. Nevertheless, maps of TOC and OC achieved an acceptable accuracy (Table IV), similar or slightly lower than that obtained in other works for bare soils, and only slightly lower than lab predictions.

\section{CONCLUSION}

i) The use of PLSR techniques in VIS-NIR spectra of soils is a suitable method to make accurate models to estimate soil organic carbon in the upper $5 \mathrm{~cm}$ of soils. The opacity of vegetation cover to optical sensors is a major problem to monitor the organic matter of soils with satellite imagery in wild landscapes, but it can be solved using these techniques applied to mixed pixels which are partially covered by vegetation. It is important to highlight that the accuracy of models is not influenced by the resolution of the spectra, making it possible to resample the spectra to wavelengths in the range of the hyperspectral images.

ii) By comparing the coefficients of absorption bands of OC and TOC PLSR models, we can explore the main molecular components of both organic carbon fractions. The results seem to highlight the more labile nature of the OC model components. The coefficients related to not-labile forms are higher in TOC than in OC model showing a greater amount of stable soil carbon components. 


\section{ACKNOWLEDGEMENTS}

This work was funded by the Government of Asturias through the project SV-PA-13ECOEMP-40. J. Peón acknowledges a PhD Grant from the University of Oviedo and a $\mathrm{PhD}$ Grant "Severo Ochoa" from the Government of Asturias (BP14-104). We also acknowledge INTA for providing the images and for the geometric and atmospheric correction.

\section{REFERENCES}

Akaike H. 1969. Fitting autoregressive models for prediction. Annals of the Institute of Statistical Mathematics 21: 243-247. DOI: 10.1007/bf02532251.

Bellon-Maurel V, McBratney A. 2011. Near-infrared (NIR) and mid-infrared (MIR) spectroscopic techniques for assessing the amount of carbon stock in soils - Critical review and research perspectives. Soil Biology \& Biochemistry 43: 1398-1410. DOI: 10.1016/j.soilbio.2011.02.019.

Ben-Dor E, Banin A. 1995. Near-Infrared Analysis as a Rapid Method to Simultaneously Evaluate Several Soil Properties. Soil Sci. Soc. Am. J. 59: 364-372. DOI: 10.2136/sssaj1995.03615995005900020014x.

Ben-Dor E, Inbar Y, Chen Y. 1997. The reflectance spectra of organic matter in the visible nearinfrared and short wave infrared region (400-2500 nm) during a controlled decomposition process. Remote Sensing of Environment 61: 1-15. DOI: 10.1016/s0034-4257(96)00120-4.

Ben-Dor E, Patkin K, Banin A, Karnieli A. 2002. Mapping of several soil properties using DAIS-7915 hyperspectral scanner data - a case study over clayey soils in Israel. International Journal of Remote Sensing 23: 1043-1062. DOI: 10.1080/01431160010006962.

Brevik EC, Cerdà A, Mataix-Solera J, Pereg L, Quinton JN, Six J, Van Oost K. 2015. The interdisciplinary nature of SOIL. SOIL 1: 117-129. DOI: 10.5194/soil-1-117-2015.

Burres L, Cheng HH, Kimble JM, Kissel DE, Lal R, Luxmoore RJ, Mausbach MJ, Rice CW, Uehara G, Wilding LD. 2001. Carbon Sequestration: Position of the Soil Science Society of America. SSSA, Madison, Wisconsin.

Cerdà A, Doerr SH. 2008. The effect of ash and needle cover on surface runoff and erosion in the immediate post-fire period. Catena 74: 256-263. DOI: 10.1016/j.catena.2008.03.010.

Chabrillat S, Goetz AFH, Krosley L, Olsen HW. 2002. Use of hyperspectral images in the identification and mapping of expansive clay soils and the role of spatial resolution. Remote Sensing of Environment 82: 431-445. DOI: 10.1016/s0034-4257(02)00060-3.

Chang CW, Laird DA. 2002. Near-infrared reflectance spectroscopic analysis of soil C and N. Soil Science 167: 110-116. DOI: 10.1097/00010694-200202000-00003.

Chang CW, Laird DA, Mausbach MJ, Hurburgh CR. 2001. Near-infrared reflectance spectroscopy-principal components regression analyses of soil properties. Soil Science Society of America Journal 65: 480-490.

Chen F, Kissel DE, West LT, Adkins W. 2000. Field-scale mapping of surface soil organic carbon using remotely sensed imagery. Soil Science Society of America Journal 64: 746-753.

Croft H, Kuhn NJ, Anderson K. 2012. On the use of remote sensing techniques for monitoring spatio-temporal soil organic carbon dynamics in agricultural systems. Catena 94: 64-74. DOI: 10.1016/j.catena.2012.01.001.

Czimczik CI, Masiello CA. 2007. Controls on black carbon storage in soils. Global Biogeochemical Cycles 21. DOI: 10.1029/2006gb002798.

Díaz González TE, Fernández Prieto JA. 1994. El paisaje vegetal de Asturias: Guía de la excursión. Itinera Geobotanica 8: 5-242.

Duarte RM, Wozniak E, Recondo C, Cabo C, Marquinez J, Fernandez S. 2008. Estimation of surface roughness and stone cover in burnt soils using SAR images. Catena 74: 264-272. DOI: $10.1016 /$ j.catena.2008.05.003. 
Ellert BH, Janzen HH, McConkey BG. 2001. Measuring and comparing soil carbon storage. In Soil processes and the carbon cycle, Lal, R, Kimble, JM, Follett, RF, Stewart, BA (eds). CRC Press; 131-146.

FAO. 2001. Soil carbon sequestration for improved land management. World Soil Resources Report 96. Food and Agriculture Organization: Rome.

Fernández-Menéndez S, Santín C, Cabo C, Menéndez RA, Álvarez MA. 2011. Incendios forestales y transferencia de carbono biomasa-suelo en áreas montañosas de clima atlántico. In XIV Congreso de la Asociación Española de Teledetección (AET): Bosques y cambio climático, Recondo, C, Pendás, E (eds): Mieres (Asturias); 217-220. DOI: 10.13140/RG.2.1.2996.4647.

Fernandez S, Marquinez J, Duarte RM. 2005. A susceptibility model for post wildfire soil erosion in a temperate oceanic mountain area of Spain. Catena 61: 256-272. DOI: 10.1016/j.catena.2005.03.006.

Gehl RJ, Rice CW. 2007. Emerging technologies for in situ measurement of soil carbon. Climatic Change 80: 43-54. DOI: 10.1007/s10584-006-9150-2.

Gomez C, Lagacherie P, Coulouma G. 2012. Regional predictions of eight common soil properties and their spatial structures from hyperspectral Vis-NIR data. Geoderma 189: 176185. DOI: 10.1016/j.geoderma.2012.05.023.

Gomez C, Viscarra Rossel RA, McBratney AB. 2008. Soil organic carbon prediction by hyperspectral remote sensing and field vis-NIR spectroscopy: An Australian case study. Geoderma 146: 403-411. DOI: 10.1016/j.geoderma.2008.06.011.

Gonzalez-Perez JA, Gonzalez-Vila FJ, Almendros G, Knicker H. 2004. The effect of fire on soil organic matter - a review. Environment International 30: 855-870. DOI: 10.1016/j.envint.2004.02.003.

Guénon R, Vennetier M, Dupuy N, Roussos S, Pailler A, Gros R. 2013. Trends in recovery of Mediterranean soil chemical properties and microbial activities after infrequent and frequent wildfires. Land Degradation \& Development 24: 115-128. DOI: 10.1002/ldr.1109.

Haaland DM, Thomas EV. 1988. Partial least-squares methods for spectral analyses. 1. Relation to other quantitative calibration methods and the extraction of qualitative information. Analytical Chemistry 60: 1193-1202. DOI: 10.1021/ac00162a020.

Hajdas I, Schlumpf N, Minikus-Stary N, Hagedorn F, Eckmeier E, Schoch W, Burga C, Bonani G, Schmidt MWI, Cherubini P. 2007. Radiocarbon ages of soil charcoals from the southern Alps, Ticino Switzerland. Nuclear Instruments \& Methods in Physics Research Section BBeam Interactions with Materials and Atoms 259: 398-402. DOI: 10.1016/j.nimb.2007.02.075.

Hatcher PG, Spiker EC. 1988. Selective degradation of plant biomolecules. In Dahlem Workshop on Humic Substances and Their Role in the Environment, Frimmel, FH, Christman, RF, Bracewell, JM (eds). Wiley, New York; 59-74.

Hbirkou C, Paetzold S, Mahlein A-K, Welp G. 2012. Airborne hyperspectral imaging of spatial soil organic carbon heterogeneity at the field-scale. Geoderma 175: 21-28. DOI: 10.1016/j.geoderma.2012.01.017.

Huang A, Li G, Fu F, Fei B. 2008. Use of visible and near infrared spectroscopy to predict klason lignin content of bamboo, Chinese fir, Paulownia, and Poplar. Journal of Wood Chemistry and Technology 28: 194-206. DOI: 10.1080/02773810802347008.

Janik LJ, Merry RH, Skjemstad JO. 1998. Can mid infrared diffuse reflectance analysis replace soil extractions? Australian Journal of Experimental Agriculture 38: 681-696. DOI: 10.1071/ea97144.

Johnson DW, Curtis PS. 2001. Effects of forest management on soil C and N storage: meta analysis. Forest Ecology and Management 140: 227-238. DOI: 10.1016/s03781127(00)00282-6.

Knicker H. 2007. How does fire affect the nature and stability of soil organic nitrogen and carbon? A review. Biogeochemistry 85: 91-118. DOI: 10.1007/s10533-007-9104-4. 
Knicker H, Gonzalez-Vila FJ, Polvillo O, Gonzalez JA, Almendros G. 2005. Fire-induced transformation of $\mathrm{C}$ - and $\mathrm{N}$-forms in different organic soil fractions from a Dystric Cambisol under a Mediterranean pine forest (Pinus pinaster). Soil Biology \& Biochemistry 37: 701718. DOI: $10.1016 /$ j.soilbio.2004.09.008.

Kuhlbusch TAJ. 1998. Black carbon and the carbon cycle. Science 280: 1903-1904. DOI: 10.1126/science.280.5371.1903.

Kuhlbusch TAJ, Crutzen PJ. 1995. Toward a global estimate of black carbon in residues of vegetation fires representing a sink of atmospheric $\mathrm{CO} 2$ and a source of O2. Global Biogeochemical Cycles 9: 491-501. DOI: 10.1029/95gb02742.

Lu P, Wang L, Niu Z, Li L, Zhang W. 2013. Prediction of soil properties using laboratory VISNIR spectroscopy and Hyperion imagery. Journal of Geochemical Exploration 132: 26-33. DOI: 10.1016/j.gexplo.2013.04.003.

Martin PD, Malley DF, Manning G, Fuller L. 2002. Determination of soil organic carbon and nitrogen at the field level using near-infrared spectroscopy. Canadian Journal of Soil Science 82: 413-422.

Mataix-Solera J, Guerrero C. 2007. Efectos de los incendios forestales en las propiedades edáficas. In Incendios Forestales, Suelos y Erosión Hídrica, Mataix-Solera, J (ed). Caja Mediterráneo CEMACAM Font Roja-Alcoi: Alicante; 5-40.

McCarty GW, Reeves JB, Reeves VB, Follett RF, Kimble JM. 2002. Mid-infrared and nearinfrared diffuse reflectance spectroscopy for soil carbon measurement. Soil Science Society of America Journal 66: 640-646.

Morra MJ, Hall MH, Freeborn LL. 1991. Carbon and Nitrogen Analysis of Soil Fractions Using Near-Infrared Reflectance Spectroscopy. Soil Science Society of America Journal 55: 288291.

Neary DG, Klopatek CC, DeBano LF, Ffolliott PF. 1999. Fire effects on belowground sustainability: A review and synthesis. Forest Ecology and Management 122: 51-71. DOI: 10.1016/S0378-1127(99)00032-8.

Novara A, Gristina L, Bodì MB, Cerdà A. 2011. The impact of fire on redistribution of soil organic matter on a mediterranean hillslope under maquia vegetation type. Land Degradation \& Development 22: 530-536. DOI: 10.1002/1dr.1027.

Okparanma RN, Mouazen AM. 2013. Visible and Near-Infrared Spectroscopy Analysis of a Polycyclic Aromatic Hydrocarbon in Soils. Scientific World Journal. DOI: $10.1155 / 2013 / 160360$.

Patzold S, Mertens FM, Bornemann L, Koleczek B, Franke J, Feilhauer H, Welp G. 2008. Soil heterogeneity at the field scale: a challenge for precision crop protection. Precision Agriculture 9: 367-390. DOI: 10.1007/s11119-008-9077-x.

Pereira P, Cerdà A, Úbeda X, Mataix-Solera J, Martin D, Jordán A, Burguet M. 2013. Spatial models for monitoring the spatio-temporal evolution of ashes after fire \&ndash; A case study of a burnt grassland in Lithuania. Solid Earth 4: 153-165. DOI: 10.5194/se-4-153-2013.

Rossello P, Baret F. 2007. VALidation of Land European Remote sensing Instruments. In CEOS/LPV-VALERI workshop: Davos, Switzerland.

Rumpel C, Chaplot V, Planchon O, Bernadou J, Valentin C, Mariotti A. 2006. Preferential erosion of black carbon on steep slopes with slash and burn agriculture. Catena 65: 30-40. DOI: $10.1016 /$ j.catena.2005.09.005.

Santín C, Doerr SH, Kane ES, Masiello CA, Ohlson M, de la Rosa JM, Preston CM, Dittmar T. 2015. Towards a global assessment of pyrogenic carbon from vegetation fires. Global Change Biology. DOI: $10.1111 / \mathrm{gcb} .12985$.

Santin C, Knicker H, Fernandez S, Menendez-Duarte R, Alvarez MA. 2008. Wildfires influence on soil organic matter in an Atlantic mountainous region (NW of Spain). Catena 74: 286295. DOI: $10.1016 /$ j.catena.2008.01.001.

Schmidt MWI, Noack AG. 2000. Black carbon in soils and sediments: Analysis, distribution, implications, and current challenges. Global Biogeochemical Cycles 14: 777-793. DOI: $10.1029 / 1999 \mathrm{gb} 001208$. 
Schulze ED, Wirth C, Heimann M. 2000. Climate change - managing forests after Kyoto. Science 289: 2058-2059. DOI: 10.1126/science.289.5487.2058.

Selige T, Boehner J, Schmidhalter U. 2006. High resolution topsoil mapping using hyperspectral image and field data in multivariate regression modeling procedures. Geoderma 136: 235-244. DOI: 10.1016/j.geoderma.2006.03.050.

Steinhardt GC, Franzmeier DP. 1979. Comparison of organic matter content with soil color for silt loam soils of Indiana. Communications in Soil Science and Plant Analysis 10: 12711277. DOI: $10.1080 / 00103627909366981$.

Stevens A, Udelhoven T, Denis A, Tychon B, Lioy R, Hoffmann L, van Wesemael B. 2010. Measuring soil organic carbon in croplands at regional scale using airborne imaging spectroscopy. Geoderma 158: 32-45. DOI: 10.1016/j.geoderma.2009.11.032.

Stevens A, van Wesemael B, Bartholomeus H, Rosillon D, Tychon B, Ben-Dor E. 2008. Laboratory, field and airborne spectroscopy for monitoring organic carbon content in agricultural soils. Geoderma 144: 395-404. DOI: 10.1016/j.geoderma.2007.12.009.

Tessier A, Campbell PGC, Bisson M. 1979. Sequential extraction procedure for the speciation of particulate trace-metals. Analytical Chemistry 51: 844-851. DOI: 10.1021/ac50043a017.

Úbeda X, Outeiro LR. 2009. Physical and Chemical Effects of Fire on Soil. In Fire Effects on Soils and Restoration Strategies, Cerdà, A, Robichaud, PR (eds). Science Publishers; 105132.

Uno Y, Prasher SO, Patel RM, Strachan IB, Pattey E, Karimi Y. 2005. Development of fieldscale soil organic matter content estimation models in Eastern Canada using airborne hyperspectral imagery. Canadian Biosystems Engineering / Le Genie des biosystems au Canada 47: 1.09-1.14.

Vasques GM, Grunwald S, Sickman JO. 2009. Modeling of Soil Organic Carbon Fractions Using Visible-Near-Infrared Spectroscopy. Soil Science Society of America Journal 73: 176184. DOI: $10.2136 /$ sssaj2008.0015.

Viscarra Rossel RA. 2007. Robust modelling of soil diffuse reflectance spectra by "baggingpartial least squares regression". Journal of near Infrared Spectroscopy 15: 39-47. DOI: 10.1255/jnirs.694.

Viscarra Rossel RA, Behrens T. 2010. Using data mining to model and interpret soil diffuse reflectance spectra. Geoderma 158: 46-54. DOI: 10.1016/j.geoderma.2009.12.025.

Viscarra Rossel RA, Walvoort DJJ, McBratney AB, Janik LJ, Skjemstad JO. 2006. Visible, near infrared, mid infrared or combined diffuse reflectance spectroscopy for simultaneous assessment of various soil properties. Geoderma 131: 59-75. DOI: 10.1016/j.geoderma.2005.03.007.

Walkley A, Black IA. 1934. An examination of the Degtjareff method for determining soil organic matter, and a proposed modification of the chromic acid titration method. Soil Science 37: 29-38.

Wang C, Wang G, Wang Y, Rafique R, Ma L, Hu L, Luo Y. 2015. Fire alters vegetation and soil microbial community in alpine meadow. Land Degradation \& Development. DOI: 10.1002/ldr.2367.

Wold S, Sjöström M, Eriksson L. 2001. PLS-regression: a basic tool of chemometrics. Chemometrics and Intelligent Laboratory Systems 58: 109-130. DOI: 10.1016/S01697439(01)00155-1.

WRB. 2014. World reference base for soil resources 2014. World Soil Resources Report 106. Food and Agriculture Organization: Rome. 


\section{Tables}

Table I. Descriptive statistics of the soil samples

\begin{tabular}{lrrrrr}
\hline & \multicolumn{2}{c}{ TOC $(\%)$} & & \multicolumn{2}{c}{ OC $(\%)$} \\
\cline { 2 - 3 } \cline { 5 - 6 } & Individual & Plot & & Individual & \multicolumn{1}{c}{ Plot } \\
\hline $\mathrm{n}$ & 89 & 12 & & 89 & 12 \\
Minimum & 4.3 & 4.5 & & 2.7 & 2.9 \\
Maximum & 63.2 & 45.9 & & 37.9 & 33.8 \\
Mean & 29.4 & 25.7 & & 19.5 & 18.1 \\
Median & 28.3 & 28.8 & & 17.4 & 18.1 \\
SD & 14.9 & 11.2 & & 10.3 & 8.3 \\
CV $(\%)$ & 50.7 & 43.6 & & 52.8 & 45.9 \\
\hline
\end{tabular}

SD: Standard deviation; CV: Coefficient of variation, $\mathrm{CV}=\mathrm{SD} \times 100 / \mathrm{Mean}$.

Table II. PLSR settings and performance statistics for prediction models of TOC and OC, based on VIS-NIR spectra

\begin{tabular}{|c|c|c|c|c|c|c|c|c|c|c|c|}
\hline \multirow[b]{2}{*}{ Property } & \multirow[b]{2}{*}{$\mathrm{n}$} & \multicolumn{5}{|c|}{ Lab-spectra } & \multicolumn{5}{|c|}{ Lab-spectra resampled to AHS } \\
\hline & & Factors & $\mathrm{AIC}$ & $\mathrm{R}_{\mathrm{cv}}^{2}$ & $\operatorname{RMSE}_{\mathrm{cv}}(\%)$ & RPD & Factors & $\mathrm{AIC}$ & $\mathrm{R}_{\mathrm{cv}}^{2}$ & $\operatorname{RMSE}_{\mathrm{cv}}(\%)$ & RPD \\
\hline TOC (\%) & 89 & 7 & $187 \cdot 3$ & 0.78 & $7 \cdot 01$ & $2 \cdot 13$ & 7 & $181 \cdot 2$ & $0 \cdot 81$ & $6 \cdot 55$ & $2 \cdot 28$ \\
\hline $\mathrm{OC}(\%)$ & 89 & 9 & $130 \cdot 2$ & $0 \cdot 88$ & $3 \cdot 53$ & $2 \cdot 93$ & 7 & $124 \cdot 8$ & $0 \cdot 89$ & $3 \cdot 47$ & $2 \cdot 97$ \\
\hline
\end{tabular}

Reflectance spectra were transformed to $\log (1 / \mathrm{R})$. n: number of samples; Factors: number of PLSR factors selected by minimizing the Akaike Information Criterion (AIC); $\mathrm{R}_{\mathrm{cv}}{ }_{\mathrm{c}}$ : coefficient of determination of cross-validation; RMSE $\mathrm{c}_{\mathrm{cv}}$ : root mean square error of cross-validation; RPD: ratio of performance to deviation.

Table III. PLSR coefficients of models for TOC and OC prediction using resampled spectra, and molecular interpretations

\begin{tabular}{|c|c|c|c|c|c|}
\hline \multirow[b]{2}{*}{ Wavelength (nm) } & \multicolumn{3}{|c|}{ Significant PLRS coefficients } & \multicolumn{2}{|c|}{ Molecular interpretations } \\
\hline & TOC & $\mathrm{OC}$ & Difference & Huang et al. (2008) & Vasques et al. (2009) \\
\hline 443 & $173 \cdot 0$ & $91 \cdot 4$ & $81 \cdot 6$ & Lignine & Recalcitrant carbon \\
\hline 560 & $62 \cdot 9$ & $65 \cdot 0$ & $-2 \cdot 1$ & Lignine and extractives & Labile carbon forms \\
\hline 591 & $180 \cdot 8$ & $138 \cdot 4$ & $42 \cdot 4$ & & \\
\hline 620 & $51 \cdot 4$ & $47 \cdot 4$ & $4 \cdot 0$ & & \\
\hline 885 & $3 \cdot 9$ & $2 \cdot 4$ & $1 \cdot 5$ & & \\
\hline 914 & $42 \cdot 7$ & $27 \cdot 8$ & $14 \cdot 9$ & & Organic pigments \\
\hline 943 & $88 \cdot 8$ & $61 \cdot 6$ & $27 \cdot 2$ & & \\
\hline 1001 & $135 \cdot 1$ & $67 \cdot 1$ & $68 \cdot 0$ & & Recalcitrant carbon \\
\hline 1590 & $26 \cdot 5$ & $-28 \cdot 0$ & $54 \cdot 5$ & Hemicellulose hydroxyls & \\
\hline 2054 & $25 \cdot 8$ & $29 \cdot 5$ & $-3 \cdot 7$ & Carbohydrates & Labile carbon forms \\
\hline 2071 & $53 \cdot 7$ & $45 \cdot 0$ & $8 \cdot 7$ & Cellulose & \\
\hline 2086 & $71 \cdot 3$ & $52 \cdot 5$ & $18 \cdot 8$ & & \\
\hline 2102 & $88 \cdot 9$ & $56 \cdot 4$ & $32 \cdot 5$ & Lignine & Recalcitrant carbon \\
\hline 2118 & $103 \cdot 1$ & $57 \cdot 3$ & $45 \cdot 8$ & & Recalcitrant carbon \\
\hline 2134 & $112 \cdot 8$ & $57 \cdot 6$ & $55 \cdot 2$ & & \\
\hline 2150 & $85 \cdot 1$ & $40 \cdot 5$ & $44 \cdot 6$ & Lignine & \\
\hline 2165 & $1 \cdot 7$ & $1 \cdot 7$ & $0 \cdot 0$ & & \\
\hline 2266 & $111 \cdot 8$ & $76 \cdot 2$ & $35 \cdot 6$ & & Recalcitrant carbon \\
\hline 2296 & $175 \cdot 0$ & $108 \cdot 7$ & $66 \cdot 3$ & & Recalcitrant carbon \\
\hline 2326 & $94 \cdot 9$ & $58 \cdot 9$ & $36 \cdot 0$ & Lignine & Recalcitrant carbon \\
\hline
\end{tabular}

Table IV. Validation of maps of soil properties with an independent dataset

\begin{tabular}{lccccccc}
\hline \multicolumn{1}{c}{ Parameter } & $\mathrm{n}$ & $\mathrm{R}^{2}$ & $\mathrm{RSE}(\%)$ & $\mathrm{a}$ & $\mathrm{b}$ & RMSEP $(\%)$ & Bias (\%) \\
\hline TOC $(\%)$ & 10 & 0.73 & 6.65 & $1.5 \pm 0 \cdot 3$ & $-11 \pm 8$ & $7 \cdot 80$ & 1.40 \\
OC $(\%)$ & 10 & 0.72 & 4.98 & $1.1 \pm 0.2$ & $0 \pm 4$ & 5.05 & 0.65 \\
\hline
\end{tabular}

$\mathrm{n}$ : number of samples; $\mathrm{R}^{2}$ : coefficient of determination; RSE: residual standard error; Observed $=\mathrm{a} \times$ Estimated $+\mathrm{b}$; RMSEP: root mean square error of prediction; Bias: mean residual. 


\section{Figures}

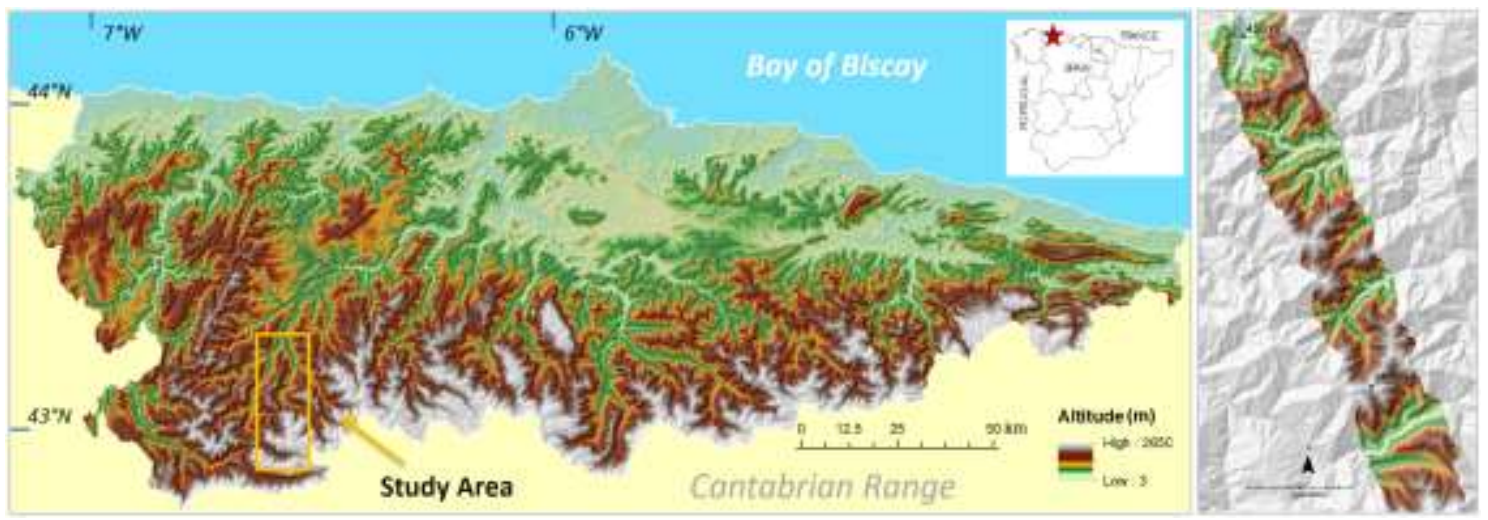

Figure 1. Location of the study area (NW Spain).
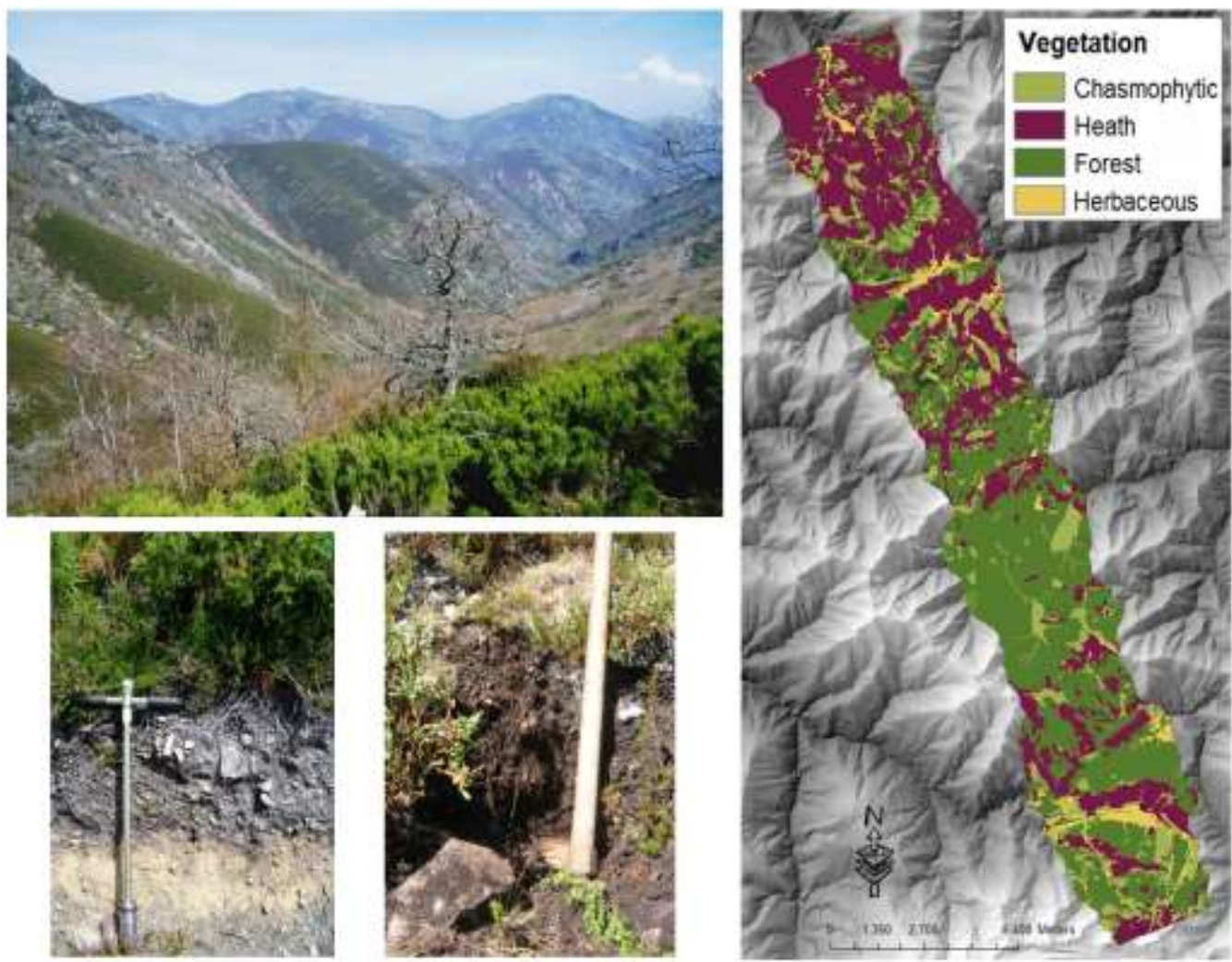

Figure 2. General view of study area and organic-enriched profiles. In vegetation map, purple represents heaths affected by frequent fires. Pale green represents typical vegetation (chasmophytic) covering skeletal and stony soils originated mainly by postfire erosion. Forest is represented in vivid green and at least grasslands for livestock use are represented in yellow. 


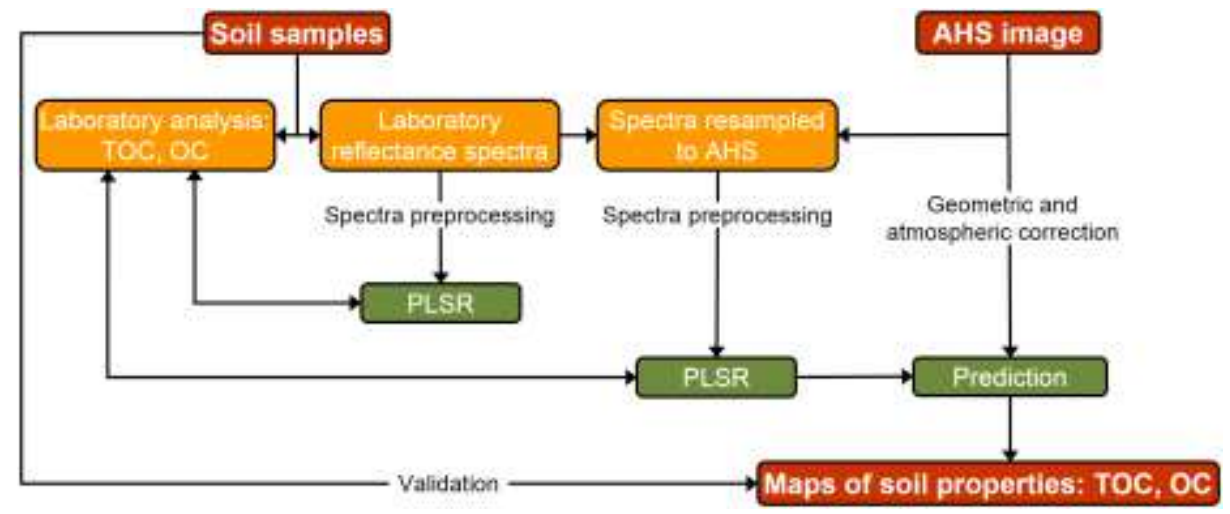

Figure 3. Processing flow chart.

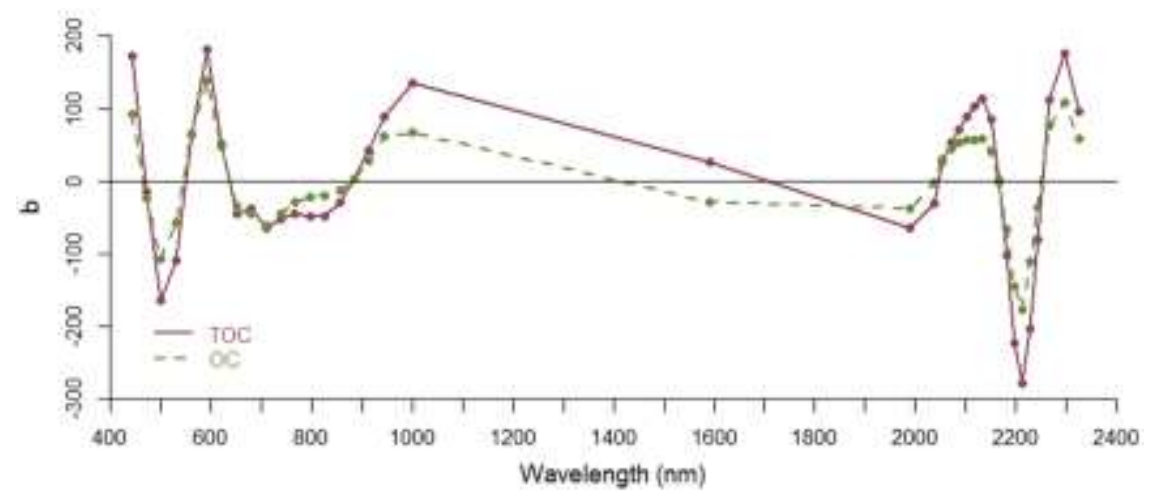

Figure 4. Regression coefficients (b) of PLSR models for TOC and OC prediction using the resampled spectra. Dots represent the 38 AHS channels used in this work.

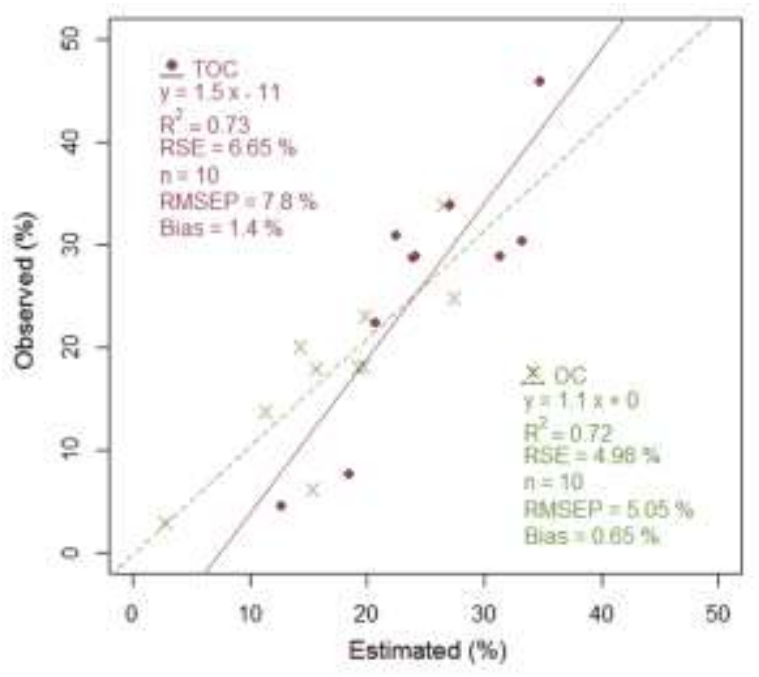

Figure 5. Scatter plot of observed against estimated soil properties using scaled maps. 

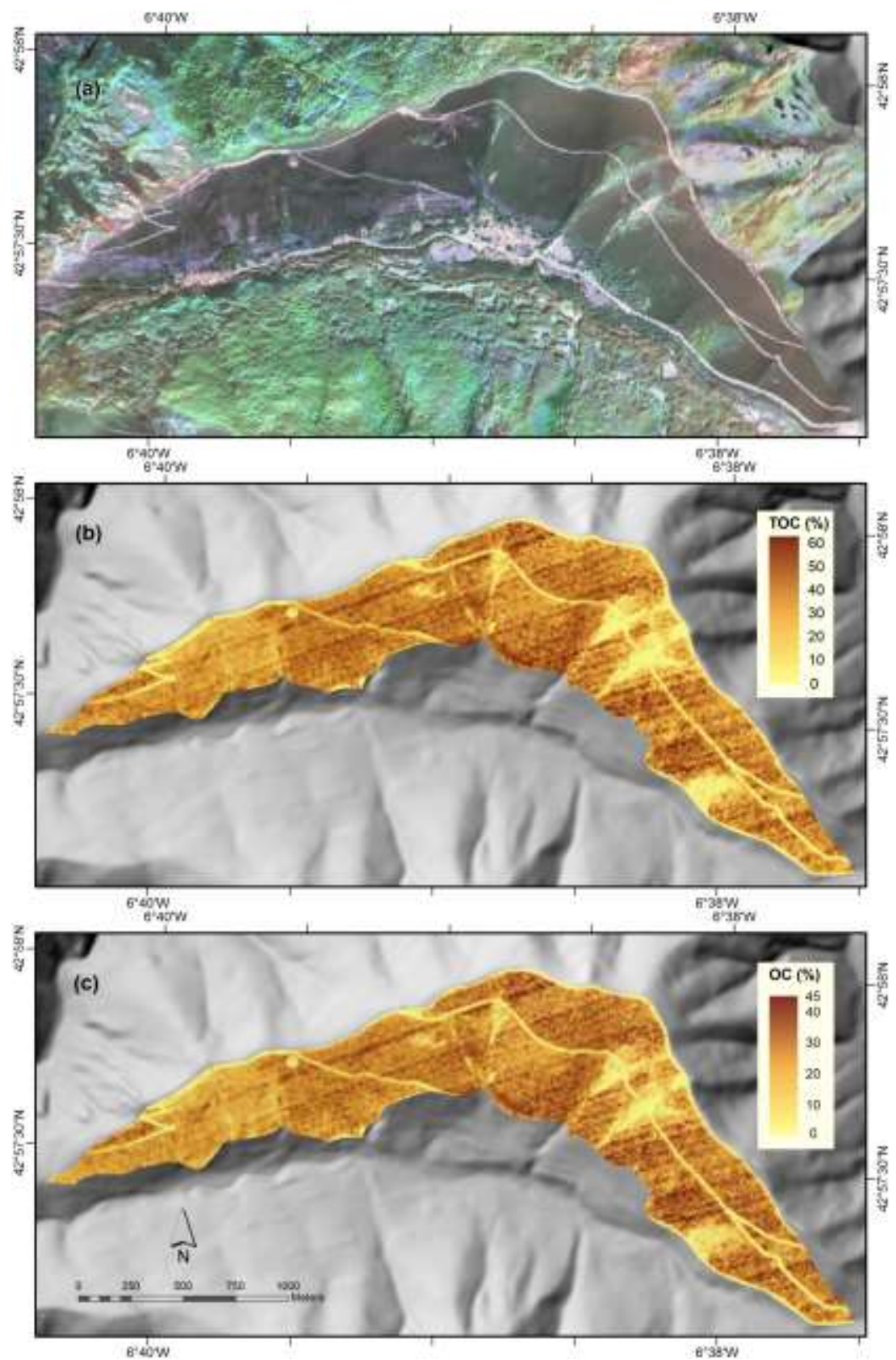

Figure 6. AHS true color composite (bands at 650, 560, and $443 \mathrm{~nm}$ in RGB) (a), and spatial distribution of the predicted TOC (b) and OC content (c) in a slope partially covered by heath, located in the south of the study area. 